\title{
Mediating Effects of Educational Level on Job Related Characteristics - Job Satisfaction Relationship
}

\author{
Maja Ivanović Đukić \\ University of Niš, Faculty of Economics, Niš, Serbia \\ Biljana Đorđević \\ University of Niš, Faculty of Economics, Niš, Serbia \\ Vinko Lepojević \\ University of Niš, Faculty of Economics, Niš, Serbia
}

\begin{abstract}
This paper will analyze the mediating influence of educational level on job related characteristics-job satisfaction relationship. The main research questions are whether the level of education influences job satisfaction. In order to answer this question, MANOVA was applied using the data obtained by the primary research on a sample of 813 employees in the companies in Serbia. Results of the study showed that job satisfaction is rising with increasing the level of education, except in case of highest level of education. Also, all job related characteristics (except contingent rewards) have significantly different influence on job satisfaction of employees with different levels of education. The results also showed that pay has greater influence on job satisfaction of the lowest educated employees than it has on job satisfaction of others. For employees with secondary education, communication and relationship with co-workers has such influence. For job satisfaction of employees with higher level of education, relationships with superiors and operating procedures have greater influence, while for the highest educated employees those are fringe benefits and nature of work.
\end{abstract}

\section{Keywords}

Job satisfaction, education of employees, job related characteristics, human resources, human resource management.

\section{Introduction}

There is no doubt that human resources are the key organizational resource. They are the only resource that can create and use other resources which will otherwise be a bunch of useless things. The importance of human resources also lies in the fact that they can be the source of sustainable competitive advantage of organizations (Barney, 1991; Wright, McMahan \& McWilliams, 1993). However, many studies found that positive influence of human resources on organizational performances and competitiveness depends on their attitudes (Cole \& Cole, 2009). Particularly, it was found that human resources are the most productive and use their full potential towards achieving organizational goals when they are satisfied with their job (Gu \& Chi, 2009; Latif et al., 2011; Kuzey, 2012).

In many studies it was found that job satisfaction influences numerous important outcomes in workplace, such as: turnover intentions (Saeed, Waseem, Sikander \& Rizwan, 2014; Larkin, 2015; Azeez, Jayeoba \& Adeoye, 2016), organizational citizenship behavior (Foote \& Li-Ping Tang, 2008; Vatsa, 2013; Swaminathan \& Jawaha, 2013), organizational commitment (Azeem, 2010; Azeez et al. 2016), job performance (Gu \& Chi, 2009; Chamundeswari, 2013; Bin, 2016) etc. Many studies also confirmed that job satisfaction of employees, as their attitude, has significant economical impact on organizational 
performances (Gu \& Chi, 2009; Latif et al., 2011; Kuzey, 2012).

Job satisfaction can be defined as an attitude towards work that occurs as a result of cognitive, affective and evaluative individual reactions to a number of different job related characteristics (Judge, Thorensen, Bono, \& Patton, 2001). It is an extremely complex phenomenon for many reasons. Firstly, because there are a number of jobs related characteristics that can induce a sense of job satisfaction among the employees. Secondly, there are a number of different individual factors (age of the employees, level of education, stage in career development, gender etc.) that may affect that certain job related characteristics could be more important for some groups of employees than for others. The influence of these (individual) factors on employees' job satisfaction has been in the focus of many studies (Wharton, Rotolo, \& Bird, 2000; Azeem, 2010; Azeez et al. 2016). This paper will examine the influence of education on job related characteristics - job satisfaction relationship, since we believe that influence of this mediating variable is insufficiently investigated, especially in domestic literature.

The main research problems of this paper are to examine whether the level of employees' education influences their job satisfaction and to identify those job related characteristics that have the greatest influence on job satisfaction of employees with different levels of education in the organizations in Serbia. The aim of the paper is to propose the set of human resource management (HRM) practices that will result in more satisfied employees with all educational levels.

The paper is organized as follows. Firstly, it will give an overview of the literature on the concept of job satisfaction and education and presents the hypothesis. The second part will explain the methodology, present the results and discussion. The final part of the paper will present conclusion and recommendations for HRM.

\section{Literature review}

Job satisfaction is one of the most frequently studied topics in management and industrial psychology from the moment when Hoppock (1937) introduced the notion of this concept. The reason for that is significance of this topic, but also its complexity since the final answers on many questions in this area are still missing.

Job satisfaction is often defined as "a pleasurable or positive emotional state resulting from the appraisal of one s job or job experiences" (Locke,
1976, p. 1304). Spector (1997) further states that job satisfaction can be viewed either as a global feeling arising from a particular job or, as a constellation of different attitudes about different job related characteristics. Such perceptions of job satisfaction are quite clearly delineated in the literature. In that line, for example, Wright et al. (1993) points out that job satisfaction is the general attitude of the individual to the job, while other authors state that job satisfaction is a multidimensional concept affected by various job related characteristics, such as: pay, working conditions, relationships with colleagues and superiors, and the like (Spector, 1997; Oshagbemi, 1999; Giri \& Kumar, 2010). Spector (1997), however, states that in the observation and analysis of job satisfaction it is much more useful if the second, analytical approach is used (facet approach) because in that case it is easier to identify job related characteristics that do not produce satisfaction of employees, or not sufficiently. Based on this finding management may create solutions for improvement of each job related characteristic (Spector, 1997).

There are different opinions about the factors which can influence job satisfaction. According to Judge and Klinger (2008) all studies that so far have investigated causality of job satisfaction in its essence were based on three types of assumptions which produced three models of job satisfaction. Those models are (Judge \& Klinger, 2008):

- Situational model,

- Dispositional model, and

- Interactional model.

The situational model of job satisfaction is based on the premise that job satisfaction stems from the job characteristics or other aspects of the environment. This model is also based on the assumption that all people have similar needs and that they can be met by the same job characteristics and, hence, produce job satisfaction (Hackman \& Oldham, 1980; Hauff, Richter, \& Tressin, T. 2015).

The dispositional model of job satisfaction states that certain relatively stable personal characteristics influence job satisfaction regardless of the job characteristics and situation (Judge, Heller, \& Mount., 2002). The factors whose influence has been investigated according to dispositional model are: psychological characteristics of employees, demographic characteristics, etc. There are many studies that examined the impact of psychological personality traits on job satisfac- 
tion (Judge et al., 2002). Five-dimensional personality model known as Big Five model was usually used in these studies. Based on this model individuals distinguish upon following dimensions: extraversion, openness to experiences, conscientiousness, agreeableness and neuroticism (McCrae \& Costa, 1991). Most of the papers confirm the strong correlation between these traits and job satisfaction. For example, based on the meta analysis that included all studies from the 1930s to the end of the 20th century, Judge and his colleagues (2002) have shown that there is a statistically significant correlation between job satisfaction and emotional stability of employees, as well as that there is a significant correlation between job satisfaction, on the one side, and neuroticism, conscientiousness and extraversion, on the other (Judge, Heller \& Mount, 2002).

Finally, the interactional model of job satisfaction is based on the assumptions that when there is congruence between the organization and the employee in terms of the values and norms of behaviour, many positive outcomes, such as organizational citizenship behaviour, low fluctuation, job satisfaction, etc., arise (Chatman, 1989). Generally speaking, this model relies on the postulate of the theory of person-environment fit according to which when there is congruence in this relationship, positive attitudes, feelings and behaviour of employees emerge.

The study we conducted is based on the assumption that job satisfaction is influenced by job related characteristics (situational model). There are different explanations of the key job related characteristics that cause employees' satisfaction. Among traditional explanations, the most famous are Herzberg`s (1965) and Locke's (Locke, Smith, Kendall, Hulin, \& Miller, 1964). Hercberg (1965) explains that there are whole groups of factors that affect satisfaction / dissatisfaction with the job. According to him, job dissatisfaction is related to working conditions such as: control, salary, company policies, physical working conditions, job security, etc., while job satisfaction is conditioned by the work results, such as: promotion, recognition, personal development, success at work and the like (Herzberg, 1965). Lock et al. (1964) explains that there are a huge number of factors that can affect employees' satisfaction which occurs if the actual outcome of work is in line with the desired one (Lock et al., 1964). Job related characteristics that we analyzed are specified in Spector's Job Satisfaction Survey (Spector, 1985). According to this author, all job related characteristics that might influence job satisfaction of the employees are divided into nine groups, such as: pay, promotion, fringe benefits, contingent reward, relationship with supervision, relationship with co-workers, operating procedures, nature of work and communication.

The significance of each job related characteristic for job satisfaction can be different for partial groups of employees (for younger and older employees, for men and women, for highly educated and low educated personnel etc.). So, different mediating variables can influence job related characteristics - job satisfaction relationship. In this paper, we will examine the mediating influence of level of education on job related characteristics - job satisfaction relationship.

Although there are a certain number of studies that examined this relationship in the literature, the level of education was mainly examined within one-dimensional models of job satisfaction. Empirical studies that examined mediating influence of level of education on job related characteristics - job satisfaction relationship are rare, especially in the countries in transition. For this reason, we will examine whether the level of education has a significant influence on job related characteristics - job satisfaction relationship of employees in the organizations in Serbia. We will observe job related characteristics in accordance with Spector's nine-dimensional model.

\section{Hypothesis}

Most of the previous research shows that job satisfaction is rising with increasing the level of education. This can be explained by the fact that more educated people generally earn more, progress faster, have a better job, and consequently their job satisfaction is higher (Clark, 1996; Wharton et al. 2000). However, there are claims that the increase in the level of education leads to increased expectations of employees that may not always be accompanied by the growth of wages and a faster progression, which can cause their dissatisfaction (Allen, 2001; Ilies \& Judge, 2003). But nevertheless, people with higher levels of education generally have higher expectations, which motivate them to further learn and grow. Consequently, a higher degree of informal education leads to further improvement of their knowledge and skills, which enable them to progress more quickly and become more satisfied with the job. Starting from the above our first hypothesis is: 
H1: Job satisfaction is higher among employees of a higher education level compared to lower educated employees.

In addition to the investigation of the relationship between education levels and job satisfaction in general, the mediating influence of level of education on partial job related characteristics job satisfaction relationship is also important. According to Maslow's theory of hierarchy of needs, different needs in humans occur depending on their lifestyle. However, the core message of Maslow's theory is fulfil the needs of low-level influences the development needs of higher rank. Having in mind that employees of different levels of education are at a different level of needs, our second hypothesis and its sub-hypothesis are:

H2: Different job related characteristics have different influence on job satisfaction of employees with different level of education.

H2a: The pay and contingent reward have greater influence on job satisfaction of employees with the lowest levels of education (primary education) compared to more educated employees.

$H 2 b$ : The communication and relationship with co-workers have a greater impact on job satisfaction of employees with secondary level of education compared to other employees.

H2c: The relationships with superiors and operating procedures have a greater impact on job satisfaction of employees with higher level of education compare to other employees.

H2d: The promotion, fringe benefits and nature of work are dimensions that have greater impact on job satisfaction for employees of the highest level of education compared to less educated employees.

\section{Sample and procedure}

In order to test previously mentioned hypothesis, the primary research was conducted. We were investigating influence of job related characteristics on job satisfaction of employees with different levels of education, based on the attitudes of employees in organizations in Serbia. The research was carried out in the period from June to September 2016. The whole procedure of sampling was realized in two phases. In the first phase we used convenient sampling that inclueded students at the final year of economics study who in the period of the research were on internship all across Serbia. In this way we obtained the data. One part of the questionnaire included questions related to general information about the respondents: gender, age, years of service, level of education, and position in the organizational structure. The second part of the questionnaire included questions related to job characteristics which influence their job satisfaction. We used Spector's Job Satisfaction Survey (JSS) (Spector, 1985). This questionnaire is designed to assess employee attitudes towards nine aspects of job that could influence job satisfaction, such as: pay, promotion, fringe benefits, contingent rewards, supervision, co-workers, operating procedures, nature of work and communication. Each aspect of job is assessed with four items (Spector, 1985) by using five-point Likert scale, ranging from 1 strongly disagree, to 5 - strongly agree. An answer of 4 or more points expresses satisfaction, while answers of 3 points express neutral opinion and below 3 points express dissatisfaction.

The study initially included 1000 respondents, employed in 28 organizations operating on the territory of the Republic of Serbia (mainly southeast of Serbia). Out of 1000 distributed questionnaires, 813 were usable, while 187 questionnaires were rejected due to inaccurate or incomplete answers. In the structure of the sample, females accounted for $42.8 \%$, while the share of men was $57.2 \%$. Regarding the age structure, the situation was as follows: $4.9 \%$ of respondents were under $25,9.5 \%$ were between 26 and $30,32.8 \%$ were between 31 and 45 year, $38.6 \%$ were between 46 and 60 , and $14.2 \%$ were over 60 . The sample structure by level of education is given in Table 1 .

Table 1 Structure of employees according to the level of education

\begin{tabular}{lcc}
\hline $\begin{array}{c}\text { Level of } \\
\text { education }\end{array}$ & $\begin{array}{c}\text { Number of } \\
\text { employees }\end{array}$ & Percentage (\%) \\
\hline Primary & 30 & 3.7 \\
Secondary & 432 & 53.1 \\
Higher & 102 & 12.5 \\
The highest & 249 & 30.6 \\
\hline Total & 813 & 100.0 \\
\hline & & Source: The authors
\end{tabular}

According to the data from Table 1, 53.1\% of employees have secondary education, $30.6 \%$ have highest education, while $12.5 \%$ have high education and only $3.7 \%$ have primary education. Originally, in the questionnaire, respondents were offered a somewhat broader range of education levels. Namely, in addition to primary education 
(II-degree), three degrees of professional qualifications (II, III and IV degrees), are included in the category "Secondary education". The category "Higher education" includes employees with all variations of VI degrees, while the category "highest education" includes all variants of degree VII. In the "Highest Education"" category, we included respondents who answered that they had MSc and PhD as well. In Table 4, "primary education" is numbered as 1, "secondary education" is number 2, "higher education" - number 3 and "highest education" - number 4.

\section{Results and discussion}

In order to check the consistency of the questions in the questionnaire, Cronbach's Alpha was first calculated. The values of Cronbach's Alpha of 0.906 indicate very good reliability and internal agreement of the scales in the sample. Compliance of individual items with total results is shown in Table 2.

According to the data in Table 2, for column Total Correlation of Questions, there is a high degree of correlation of each item with total results. Since all values in the Cronbach's Alpha column in case of deleting questions are less than the final alpha value (0.906), it is advisable for all items in the existing scale to remain, and that this scale is comparable to research based on such a scale. Also, the mean correlation between the items is 0.513 , and the correlation of the pairs of items is from 0.384 to 0.767 , which indicates that the correlation between the items is strong.

Table 2 Measuring scale compliance

\begin{tabular}{lcc}
\hline \multicolumn{1}{c}{ Questions } & $\begin{array}{c}\text { Total } \\
\text { correlation of } \\
\text { questions }\end{array}$ & $\begin{array}{c}\text { Cronbach's } \\
\text { Alpha in case of } \\
\text { questions } \\
\text { exclusion }\end{array}$ \\
\hline Pay & .809 & .886 \\
Promotion & .795 & .886 \\
Fringe benefits & .721 & .892 \\
Contingent rewards & .641 & .899 \\
Supervision & .621 & .900 \\
Co-workers & .809 & .886 \\
Operating proce- & .440 & .905 \\
dures & .558 & .901 \\
Nature of work & .748 & .891 \\
Communication & .906 & \\
\hline Crnbach's Alpha & 813 & \\
\hline Sample size & & \\
\hline
\end{tabular}

Source: The authors
Descriptive statistics and multivariate analysis of variance were applied to verify the validity of the hypothesis. After checking the assumptions related to the implementation of MANOVA - the size of the sample, the normality of distribution, the linearity, the homogeneity of the matrix of variance and covariance, the multicollinearity singularity, we conclude that all the conditions for the implementation of the multivariate analysis of variance have been met.

Table 3 Multivariate tests

\begin{tabular}{|c|c|c|c|c|c|c|}
\hline & & $\frac{0}{\frac{0}{N}}$ & ᄂ & 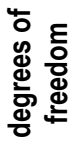 & $\frac{0}{\frac{0}{\pi}}$ & 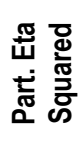 \\
\hline \multirow{4}{*}{ 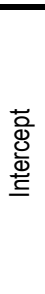 } & $\begin{array}{l}\text { Pillai's } \\
\text { Trace }\end{array}$ & .950 & 1677 & 9 & .000 & .950 \\
\hline & $\begin{array}{l}\text { Wilks' } \\
\text { Lambda }\end{array}$ & .050 & 1677 & 9 & .000 & .950 \\
\hline & $\begin{array}{l}\text { Hotelling's } \\
\text { Trace }\end{array}$ & $\begin{array}{c}18.8 \\
50\end{array}$ & 1677 & 9 & .000 & .950 \\
\hline & $\begin{array}{l}\text { Roy's } \\
\text { Largest } \\
\text { Root }\end{array}$ & $\begin{array}{c}18.8 \\
50\end{array}$ & 1677 & 9 & .000 & .950 \\
\hline \multirow{5}{*}{ 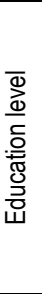 } & $\begin{array}{l}\text { Pillai's } \\
\text { Trace }\end{array}$ & .338 & 10.42 & 27 & .000 & .158 \\
\hline & $\begin{array}{l}\text { Wilks' } \\
\text { Lambda }\end{array}$ & .763 & 11.85 & 27 & .000 & .132 \\
\hline & $\begin{array}{l}\text { Hotelling's } \\
\text { Trace }\end{array}$ & .338 & 12.52 & 27 & .000 & .145 \\
\hline & Roy's & & & & & \\
\hline & $\begin{array}{l}\text { Largest } \\
\text { Root }\end{array}$ & .351 & 20.96 & 9 & .000 & .222 \\
\hline
\end{tabular}

Source: The authors

Table 3 provides a set of multivariate tests that indicate that there is a statistically significant impact of the level of education on the level of job satisfaction. The results of multivariate analysis are shown in Table 4.

As Table 4 shows, job satisfaction differs among employees with different level of education. Also, job satisfaction is rising with increasing the level of education, except in case of highest level of education. So, our first hypothesis (H1) is partially confirmed.

More precisely, the least job satisfaction is found among the least educated employees (primary level of education-3.69). Somewhat higher average job satisfaction is characteristic for employees with secondary level of education (3.91). The highest level of job satisfaction is found among employees with higher education (3.96). However, job satisfaction of the most educated employees (highest level of education) is slightly lower compared to the previous level of education 
(3.93). This can be explained by specific circumstances in Serbia. Serbia is characterized by a high level of unemployment and it is very common that people with the highest level of education accept low paid jobs (because they do not have the possibility of choosing), so their job satisfaction is lower than expected.

Table 4 MANOVA test

\begin{tabular}{|c|c|c|c|c|c|c|c|c|}
\hline \multirow{2}{*}{$\begin{array}{l}\text { Causes of job } \\
\text { satisfaction }\end{array}$} & \multicolumn{4}{|c|}{ Level of education } & \multirow{2}{*}{$F$} & \multirow{2}{*}{$\begin{array}{c}\mathrm{p}- \\
\text { value }\end{array}$} & \multirow{2}{*}{$\begin{array}{l}\text { Partial } \\
\text { Eta Sq. }\end{array}$} & \multirow{2}{*}{ Bonferroni Test } \\
\hline & 1 & 2 & 3 & 4 & & & & \\
\hline Pay & 4.25 & 4.04 & 3.88 & 3.75 & 15.16 & .000 & .144 & $1-3.1-4.2-4.2-3$ \\
\hline Promotion & 3.15 & 3.58 & 3.61 & 4.26 & 11.68 & .000 & .082 & $1-2.1-3.1-4.2-4$ \\
\hline Fringe benefits & 4.06 & 3.97 & 4.06 & 4.86 & 14.51 & .000 & .064 & $1-4.2-4.3-4$ \\
\hline Contingent rewards & 4.31 & 4.65 & 4.84 & 3.87 & 3.42 & $N S^{*}$ & .013 & 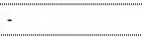 \\
\hline Supervision & 3.70 & 3.88 & 4.01 & 3.88 & 2.23 & .003 & .007 & $1-2 \cdot 1-3 \cdot 1-4.2-4$ \\
\hline Co-workers & 3.40 & 3.91 & 3.86 & 3.87 & 13.06 & .000 & .046 & $1-2.1-3.1-4$ \\
\hline Operational procedures & 3.95 & 3.80 & 3.96 & 3.45 & 10.74 & .007 & .055 & $1-4.2-4.3-4$ \\
\hline Nature of work & 3.08 & 3.49 & 3.65 & 3.95 & 12.44 & .000 & .040 & $1-2.1-3.1-4.2-4$ \\
\hline Communication & 3.36 & 3.81 & 3.79 & 3.48 & 13.52 & .000 & .054 & $1-2.1-3.1-4.2-4.3-4$ \\
\hline Total satisfaction & 3.69 & 3.91 & 3.96 & 3.93 & & & & \\
\hline Number of respondents & 30 & 432 & 249 & 102 & & & & \\
\hline
\end{tabular}

*NS - Non sigificant

Table 4 also shows that contingent rewards are the only job related characteristic which has no statistically significant different influence on job satisfaction of employees with different levels of education. The mean values of this job related characteristic (between 3.87 and 4.84) are above the average job satisfaction (3.87). So we may conclude that contingent rewards are very significantly for job satisfaction of all employees regardless of a level of education. All other job related characteristics (pay, promotion, fringe benefits, operating procedures, communication, relationship with supervision and co-workers) have significantly different influence on job satisfaction of employees with different levels of education (information of statistically significant differences between career stages in all characteristics can be found in Table 4 in the column p-value and Bonferroni column). So, our second hypothesis (H2) that different job related characteristics have different influence on job satisfaction of employees with different levels of education is partially confirmed (with the exception of contingent rewards). The highest variability in the job related characteristic - job satisfaction relationship conditioned by level of education are in the following job related characteristic: pay (Partial Eta Squa-0.144, There is no difference between 1-2 level of education as well as 3-4 level of education - Bonferroni) and promotion (Partial Eta Squa-0.086, There is no difference between 2-3 level of education as well as 3-4 level of education - Bonferroni).
Regarding the sub-hypothesis $\mathrm{H} 2 \mathrm{a}$, we assumed that pay and contingent reward have greater influence on job satisfaction of employees with the lowest levels of education (primary education) compared to more educated employees. The results in Table 4 indicate that employees' satisfaction with pay is the highest among the most uneducated employees, and it decreases with increasing levels of education. But this is not the case with contingent rewards. As noted above, this job related characteristic has approximately the same impact on the job satisfaction of employees with all education levels. Having in mind previously presented results we may conclude that sub-hypothesis $\mathrm{H} 2 \mathrm{a}$ is not confirmed.

Sub-hypothesis $\mathrm{H} 2 \mathrm{~b}$ was that communication and relationship with co-workers have a greater impact on job satisfaction of employees with secondary level of education compared to other employees. The results we obtained show that employees' satisfaction with communication $(3,81)$ is higher among employees with secondary level of education compared to other employees as well as compared to average job satisfaction with this job characteristic for all employees $(3,81$ /3,61 average). A similar situation is with the other job related characteristics. Satisfaction with relationship with co-workers $(3,91)$ is higher among employees with secondary level of education compared to other employees as well as compared to average job satisfaction with this job characteristics for all employees (3,91/3,76 average). We may conclude that hypothesis $\mathrm{H} 2 \mathrm{~b}$ is confirmed.

Sub-hypothesis $\mathrm{H} 2 \mathrm{c}$ was that the relationships with superiors and operating procedures have a greater impact on job satisfaction of employees with higher level of education compared to other employees. The results we obtained show that employees' satisfaction with both job related characteristics among employees with higher level of education is higher compared to other employees as well as compared to average job satisfaction with those job related characteristics for all employees (relationships with superiors 4.01/3.86 average; operating procedures 3.96/3.79 average). Therefore, we may conclude that hypothesis $\mathrm{H} 2 \mathrm{c}$ is confirmed.

A similar situation is with sub-hypothesis $\mathrm{H} 2 \mathrm{~d}$. The results we obtained show that employees' satisfaction with promotion, fringe benefits and nature of work among the highest educated employees is higher compared to other employees as well as compared to average job satisfaction with 
that job related characteristics. We may conclude that hypothesis $\mathrm{H} 2 \mathrm{~d}$ is confirmed

\section{Conclusion}

Based on the above, it can be concluded that job satisfaction is a very important phenomenon in working place, which can be moderated by numerous factors. In this paper we investigated influence of level of education on job related characteristics - job satisfaction relationship of the employees in enterprises in Serbia. We examined whether education influences job satisfaction of employees in enterprises in Serbia as well as weather different job related characteristics (specified in Spector's model) have different influence on job satisfaction for employees with different levels of education.

It was found that job satisfaction is different among the employees with different levels of education, and that it increases with the increase of the levels of education, except in the case of the highest educated employees. This finding can be explained by the specific circumstances in Serbia. Due to the high level of unemployment rate, employees with the highest level of education often accept the jobs that do not correspond to their competences.

Research has also shown that the level of education mediate the relationship between jobs related characteristics and job satisfaction. The only exception is contingent rewards. The satisfaction with contingent rewards is equally very high for all employees regardless of their level of education. The research further showed that various forms of rewards (pay, contingent rewards, fringe benefits) the have greatest impact on job satisfaction of employees with the lowest level of education (primary education). This can be explained by the fact that in Serbia the average pay, although not high, has a high significance. It enables this category of employees to satisfy their basic existential needs which are the most important for them. Based on the obtained results, we see possibility for increasing the job satisfaction of this group of employees in improving the communication, as well as in improving the relationship with co-workers. Communication can be improved by introducing the new channels of communication, such as ,open doors" where higher level management will reserve a couple of hours of week or month for communication with employees. Also, in today's digital era, when almost everyone has basic knowledge of using IT technology, introducing electronic channels of communication would be also a suitable measure. Enhancing relationship with co-workers could be achieved by introducing more team's assignments and rewarding for teams' results.

The communication and relationship with coworkers are job related characteristics that have a higher influence on job satisfaction for employees with secondary education than for others. Based on the obtained results (low average satisfaction) we see possibility for increasing the job satisfaction of this group of employees in improvement the possibility for promotion as well as in nature of work. Higher satisfaction with promotion could be achieved by strictly implementation of the principle that achieved results in the past should be the primary criteria for advancement and not other criteria (not, for example, political background or something else). Improvement in domain of nature of work could be achieved by introducing job rotation, job enlargement, and job enrichment.

Research has also shown that the relationships with superiors and operating procedures have a greater impact on job satisfaction of employees with higher level of education compared to other employees. We see possibility for improving the human resources management practices regarding this category of employees in their redeploying or in redesigning their job so that work tasks become more motivated and challenging. Job characterises model introduced by Hackman and Oldham (1980) would be a suitable solution.

Finally, the research showed that employees with the highest level of education are the most satisfied with fringe benefits, promotion and nature of work. Among these job related characteristics they are the most satisfied with fringe benefits. This can be explained by the fact that fringe benefits are usually the highest for this category of employees, and at the same time, the needs that can be met by them are highly ranked. We see opportunity for increasing the job satisfaction of this category of employees in improving the communication since this job related characteristic is the most unfavourably assessed by them. As we said earlier, introducing new channels of communication and higher visibility of higher level of management would be useful measures. 


\section{References}

Allen, J. \& Van der Velden, R. (2001) Educational mismatches versus skills mismatches: effects on wages, job satisfaction and on the job search. Oxford Economic Papers, 53 (3), 434-452.

Azeem, S. M. (2010). Job satisfaction and organizational commitment among employees in the Sultanate of Oman. Psychology, 1, 295-299.

Azeez, R. O., Jayeoba, F., \& Adeoye, A. O. (2016). Job Satisfaction, Turnover Intention And Organizational Commitment. Journal of Management Research, 8 (2), 102-114.

Barney, J. (1991). Firm Resources and Sustained Competitive Advantage. Journal of Management, 17 (1), $99-120$

Bin, A. S. (2016). The relationship between job satisfaction, job performance and employee engagement: An explorative study. Issues in Business Management and Economics, 4 (1), 1-8.

Chamundeswari, S. (2013). Job satisfaction and performance of school teachers. International Journal of Academic Research in Business and Social Sciences, 3 (5), 420-428.

Chatman, J. A. (1989). Improving interactional organizational research: A model of personorganization fit. Academy of Management Review, 14 (3), 333-349.

Clark, A. E. (1996). Job satisfaction in Britain. Journal of Industrial Relations, 32 (4), 189-217.

Cole, L.E., \& Cole, M.S. (2009). Employee Satisfaction and Organizational Performance: A Summary of Key Findings from Applied Psychology. Retrieved January 25, 2017, from http://www.teammax.net/files/LiteratureReview.pdf

Foote, D. A., \& Li-Ping Tang, T. (2008). Job satisfaction and organizational citizenship behavior (OCB); Does team commitment make a difference in self-directed teams? Management Decision, 46 (6), 933-947.

Giri, V.N. \& Kumar, B.P. (2010). Assessing the impact of organizational communication on job satisfaction and job performance. Psychological Studies, 55 (2), 137143.

Gu Z., \& Chi, R.S.S. (2009). Drivers of job satisfaction as related to work performance in Macao casino hotels: An investigation based on employee survey. International Journal of Contemporary Hospitality Management, 21 (5), 561- 578.

Hackman, J. R., \& Oldham, G. R. (1980). Work redesign. Reading, MA: Addison Wesley.

Hauff, S., Richter F. N., \& Tressin, T. (2015) Situational job characteristics and job satisfaction: The moderating role of national culture. International Business Journal, 24 (4), 710-723.

Herzberg, F. (1965). The new industrial psychology. Industrial and Labor Relations Review, 18 (3), 364-376.

Hoppock, R. (1937). Job satisfaction of psychologists. Journal of Applied Psychology, 21 (3), 300-303.

Illies, R., \& Judge, T. A. (2003). On the heritability of job satisfaction: The mediating role of personality. Journal of Applied Psychology, 88 (4), 750-759.

Judge, T. A., \& Klinger, R. (2008). Job satisfaction: Subjective well-being at work. In M. Eid, \& R. Larsen (Eds.), The Science of Subjective Well-Being (Ch. 19, pp. 393-413). New York: Guilford Publications.
Judge, T. A., Heller, D., \& Mount, M. K. (2002). Five-Factor Model of Personality and Job satisfaction: A MetaAnalysis. Journal of Applied Psychology, 87 (3), 530 541.

Judge, T. A., Thorensen, C.J., Bono, J. E., \& Patton, G. K. (2001). The job satisfaction-job performance relationship: A qualitative and quantitative review. Psychological Bulletin, 127 (3), 376-407.

Kuzey, C. (2012). Impact of Health Care Employees' Job Satisfaction On Organizational Performance Support Vector Machine Approach. European Journal of Economic and Political Studies, 5 (1), 65-89.

Larkin, I. M. (2015). Job satisfaction, organizational commitment, and turnover intention of online teachers in the $\mathrm{K}-12$ setting. Doctor of Education in Instructional Technology Dissertations. Paper 2. . Retrieved January 25, 2017, from http://digitalcommons.kennesaw.edu/instruceddoc_etd/ 2

Latif, M. S., Ahmad, M., Qasim, M., Mushtaq, M., Ferdoos, A., \& Naeem, H. (2013). Impact of employee's job satisfaction on organizational performance. European Journal of Business and Management, 5 (5), 166-171.

Locke, E. A., Smith, P. C., Kendall, L. M., Hulin, C. L. \&Miller, A. M. (1964). Convergent and discriminant validity for areas and methods of rating job satisfaction. Journal of Applied Psychology, 48 (5), 313-319.

Locke, E. A. (1976) The nature and causes of job satisfaction. In M. D. Dunnette (Ed.), Handbook of Industrial and Organizational Psychology, (pp. 12971349). Chicago: Rand McNally College Publishing Company.

McCrae, R. R. \& Costa, P. T. (1991). Adding liebe und arbeit: The full fivefactor model and well-being. Personality and Social Psychology Bulletin, 17 (2), 227232.

Oshagbemi, T. (1999). Overall job satisfaction: how good are single vs. multiple item measures? Journal of Managerial Psychology, 14 (5), 388-403.

Saeed, I., Waseem, M., Sikander, S., \& Rizwan, M. (2014). The relationship of turnover intention with job satisfaction, job performance, leader member exchange, emotional intelligence and organizational commitment. International Journal of Learning and Development, 4 (2), 242-256. https://doi.org/10.5296/ijld.v4i2.6100

Spector, P. E. (1997). Job Satisfaction: Application, Assessment, Causes, and Consequences. United Kingdom: Sage Publica -tions Ltd.

Spector, P.E. (1985). Measurement of human service staff satisfaction: Development of the job satisfaction survey. American Journal of Community Psychology, 13 (6), 693-713.

Swaminathan, S. \& Jawahar, D. (2013). Job satisfaction as a predictor of organizational citizenship behavior: an empirical study. Global Journal of Business research, 7 (1), 71-80.

Vatsa, N. (2013). Relationship of Job Satisfaction With Organization Behavior. International Journal of Education and applied research, 3 (2), 17-21.

Wharton, A. S., Rotolo, T., \& Bird, S. R. (2000) Social context at work: a multilevel analysis of job satisfaction. Sociological Forum, 15 (1), 65-90. 
Wright, P., McMahan, P., \& McWilliams, A. (1993). Human

Resources and Sustained Competitive Advantage: A

Resource-Based Perspective. Los Angeles: Center for

Effective Organizations-Marshall School of Business.

\section{$\triangle$ Correspondence}

\section{Maja Ivanović Đukić}

Faculty of Economics

Trg kralja Aleksandra Ujedinitelja 11, 18105 Niš, Serbia

E-mail: maja.ivanovic@eknfak.ni.ac.rs 